\title{
BEYOND EPISTEMOLOGICAL RELIGIOUS TRUTH A REFLECTION OF THE OTHER OUTSIDE “TRUE-FALSE" CATEGORY
}

\author{
Yohanes Slamet Purwadi \\ Inter Religious Studies Graduate School Gadjah Mada University \\ and Parahyangan Catholic University Bandung \\ Email: yohanpurwadi@yahoo.co.id \\ Banawiratma \\ Duta Wacana Christian University Yogyakarta \\ Sahiron Syamsuddin \\ Sunan Kalijaga Islamic State University Yogyakarta
}

\begin{abstract}
ABSTRAK
Makalah ini akan memaparkan problematik dan dinamika "kebenaran relijius" dalam konteks kebebasan beragama di Indonesia. Arus umum diskursus kebebasan beragama di Indonesia didominasi oleh bahasa dan pemahaman religius yang bersifat epistemologis. Wujud diskursusnya penuh dengan kategori-kategori epistemologis, seperti: 'sesat-tidak sesat' atau 'benar-salah' 'penodaan agama' sehingga membuka celah bagi menyusupnya monopoli dan fiksasi kebenaran. Implikasinya, kebenaran religius yang bersifat epistemologis cenderung tidak ramah terhadap 'yang lain'.

Sebagai alternatif, makalah ini mencoba menggelarkan modus pemahaman yang lebih ramah dan inclusif, yakni modus pemahaman religius yang bersifat eksistensial. Melalui teropong hermeneutika Ricouer, pertama, modus pemahaman eksistensial dimaksudkan sebagai kritik atas monopoli dan pembakuan kebenaran religius. Kedua, modus ini mencoba mengakomodir the other atau 'yang lain' sebagai horison interpretatif dan "jalan melingkar" untuk memperkaya pemahaman religius dan juga pemahaman diri.
\end{abstract}

Kata Kunci: Kebenaran Religius Epistemologis, Kebenaran Religius Eksistensial, Hermeneutika Ricoeur, Makna, Pemahaman Diri, 'yang lain'

\section{ABSTRACT}

The aim of this paper is to investigate the problematics and dynamics of 'religious truth', put into the context of religious freedom in today's Indonesia. Generally speaking, the dominant discourse of religious truth in Indonesia is heavily determined by epistemological knowledge and understanding. In everyday language, through which this knowledge is produced and distributed, some epistemological categories, such as 'deviant-believer', 'truefalse', and even 'blasphemy', are commonly applied. Here, in the problem lies these categorizations might open up possibility for the fixation of 'truth', which in turn, inclines to subordinate what is generically referred to as 'the other'. Seeking an alternative, this paper attempts to develop a more favorable and inclusive religious understanding, one which is indebted to the mode of existential religious understanding, including the linguistic model of translation. Employing Ricouerian's hermeneutics, this mode of existential understanding offers valuable critique of the monopoly and orthodoxy of religious truth. Moving further, it promotes 'the others' as an interpretative horizon and a 'circling way', through which we enrich our religious understanding, as well as selfunderstanding.

Keywords: Epistemological Religious Truth, Existential Religious Truth, Ricoeur's Hermenutics, Linguistic Model of Translation, Meaning, Self- Understanding, The Others 


\section{INTRODUCTION}

Religious freedom has always been a crucial issue in Indonesia. On behalf of religion, and God for certain, some minority groups, which addressed with several namecalling: deviant (sesat) or heathen (kafir) are aggressively attacked and assaulted. The number of this religious violent is continuously mounted, particularly after the New Order period. Setara Institute reported that during 2011 there were various religious intolerance and violence that involve state as an actor both by commission or tindakan aktif and ommission or tindakan pembiaran (Hasani and Tigor, 2012: 22-23) One might recalled to the New Order, such conflicts was rarely been found, or safely to say this matter would not emerge in public nor became a public attention or object of knowledge. The State had controlled everything.

Through its repressive and authoritative power, any 'subversive' action was silenced before it even had a chance to speak. And under the jargon of 'safety and orderliness', religion was considered as a public threat; it was believed of having potential to rise conflict and ruin the stability of the State. Apparently, that was the main reason why the State preferred militaristic approach rather than diplomatic ones; the State might, for instance develop policy to liberate religion. It is also applied in political aspect.

During the New Order, political parties were dissolved into three political parties only.So, it was understandable why the relation among religion framed by using the ferminology of "inter-religious harmony" kerukunan beragama) rather than "religious freedom" (kebebasan beragama).
Compare to the New Order, the relation between the State and religion during the postNew Order is far more complex. The power of the State is constrained. It has become less and less authoritative. Its repressive power is soften. On the other hand, the concepts of nation-state and citizenship politics as hegemonic instrument are slowly faded along with bankruptcy of the New Order. Yet, after the New Order period ended, the State is suffered from serious legitimation crisis.

Consequently, it encourages the emergence of identity-based politics; to name one example among many- as articulated in religion-based politics. Within such socio-politics constellation, the State, which experiences legitimation crisis, does not have another option but to compromise with the interest of religious-based politic group, especially majority ones. However, the "soft state" stamp which has been printed to the State in the post-New Order should be situated within the conjuncture of aforementioned socio-politics condition (Nordholt, 2008: 18-19).

Considering the conjuncture of sociopolitics condition as suggested earlier, following questions may come to mind: how should religious truth understood within the context of religious freedom in Indonesia? What mode of religious understanding and social episteme dominate the discourse of religious freedom in Indonesia? What kind of "politics of truth" frames the discourse of religious freedom in Indonesia? And, what mode of religious understanding can be generated as a common language to encourage the birth of genuine religious freedom?

Surely, the answers to those questions deserve more than just a sentence or two. The discourse of religious freedom is very complex, indeed. Herein the contestation 
of power takes place as the State and other interests groups struggle to retain their hegemonic influence toward the society. Furthermore, this contestation shapes the look of actual religious freedom in Indonesia. It also brings to light other fundamental concepts, namely politics of truth, as well as religious understanding and religious truth.

To some extent, this contestation is merely a mode of expression for conflictive religious truth and understanding. How people respond, consider, and act on the name of their religion, of course - do not based on a blind faith. But rather, it is driven by certain epistemic framework. This modality gives legitimation and motivation to people's behavior. Certain labeling, such as: 'heresy' (ajaran sesat), 'apostate' (murtad), 'deviant' (menyimpang), or even 'desecration' (penodaan agama) is consciously addressed to 'the others' and considered as sort of self-virtue. Or to be more concise, judgments function as manifestation of religious understanding.

\section{DISCUSSION \\ Epistemological Religious Truth}

Normatively speaking, Indonesia is fully submitted to religious freedom principle Religious life is guaranteed legally by constitution of the State (Wikisource, 2012: 1). Yet, the interpretation tends to be problematic. It is important to note that, the discourse of religious freedom is not solely defined by 'who can speak', but also its epistemic pattern. Officially, the government acknowledges five religions while others categorized as a belief.

For instance, please consider the case of Ahmadiyah below. It will help us identify the dynamics of religious freedom in Indonesia, particularly when it comes to dominant religious truth and understanding. To comprehend this case better, it will be analyzed by employing hermeneutical discourse analysis. In this manner, our concern will focus on the foundation and criteria used by the State and majority groups to claim Ahmadiyah as a minority group while put into the larger context of religious freedom.
As a hermeneutical discourse, the issue of religious freedom is much more concern in anthropological implication of religious truth rather than religious truth per se (Garret, 1978: 3). What is interesting here are, legal basis and argumentation for banning Ahmadiyah is heavily relied on theological language and assumption. What makes it more interesting is that this theological language also based on certain religious understanding, which gives legitimation to ban Ahmadiyah. Some theological categories, to name a few: 'heresy', 'deviant', and even 'religious insult' are recklessly employed.

In addition, one point stated on Indonesian Joint Ministerial Decree (Surat Keputusan Bersama Tiga Menteri): “To warn and command whole citizen not to recite and interpret certain religion in Indonesia by referring to UU No 1 PNPS 2005 about religious insult prevention" (Andi R, 2011: 1). It is assumed that violating the rights of Ahmadiyah follower (commonly refer to as Ahmadis) is permissible as a logical consequence to their 'false belief': "their belief is heretical, it is logical if their rights violated by law!"

Terminologies as mentioned earlier, whether 'deviant' or 'heresy'- prevail in certain discourse of religious truth. Simply put the interpretation of religious truth operates through a certain pattern, which henceforth would be called epistemological religious truth. It is identifiable by its 'truefalse' criteria to claim religious truth, includes Ahmadiyah. In this sense, religious teachings is treated like scientific proposition with set of fixed procedure and criteria to verify its truthfulness.

Ahmadiyah is claimed to be false as if it has been proven through scientific assessment. Here, the rule is rather simple: there is only one single truth, and the rest are totally false. When it comes to truth, it is always in a singular form rather than plural. Unsurprisingly, religion is simply reduced as 'a system of thought', which can be verified whether it is true or not (Brockelman, 1992: 141-142). Religious truth is assumed to work 
as reflexivity model, which applied in science (Ricoeur, 1965: 170).

'True-false' criteria in interpreting religious truth is used in a similar manner to measure scientific proposition. Besides, religious truth is also simplified as set of objective belief statements. More precisely, it is considered as an adequacy, kind of a readyto-use tool kit that is applicable to assess and evaluate 'the truth' while ignoring specific context and situation.

Moreover, it is important to note that religious truth always involves interpretation. Interpretation is not entirely independent, but rather dependent on specific mode, which functions as a 'metaphor'. By metaphor, I mean as a specific mode or way to understand and experience one concept in terms of another concept (Lakoff and Johnson, 2003: 3-6). However, metaphor does not only help us to understand religious truth through comparison or analogy, but also, more importantly, to structure our perception and understanding toward religious truth (Lakoff and Johnson, 2003: 3-6).

It appears that the main problem lies in interpretation of 'true-false' terminology. If the metaphor borrowed is from scientific mode, scientific criteria will structure our perception and comprehension toward religious truth. Yet, these criteria are problematic, especially when applied to assess religious truth. Simply put, if 'true-false' criterion is operated as scientific discourse, in a sense that it would evaluate the degree of compatibility between perception and reality, between concept and objective reality- herein emerges two categories of religion: true religion (orthodoxy) and false religion (heterodoxy). Besides, there will be claim toward religious truth, which objectively in accordance with God's Will, and so forth. Thus, religious truth from 'epistemological' mode standpoint can be briefly described as followed:

" ... an interpretative idea is supposed to carry over what is important in the object into the interpreter in the respect in which the idea represents the object. If it does carry over the value, it is true and if it does not, it is false. Truth is thus a dyadic value: either true or false. To use the Aristotelian language, a claim is true if it says of what is that it is and what is not that is not" (Neville, 2001: 163).

Thus, this so-called religious truth is easily fall into absolute-monolithic religious understanding. Absolutely, this kind of interpretation tends to violate religious freedom. Indeed, the basic assumption of absolutism and monadism is in stark contrast to the logic of religious freedom. As a result, the society becomes more monolithic and socially exclusive, which makes it nearly impossible for 'the other' to survive. The case of Ahmadiyah, as suggested in earlier discussion, clearly illustrates how the absolute-monolithic religious understanding may legitimize and motivate marginalization and social exclusion by labelling 'deviant and misleading' (sesat dan menyesatkan). Please consider following statement:

"(T)he decisions and the recommendations of the World Mosque Council ...entirely confirm what had been established by [the] research bureau... of the Saudi Arabian kingdom: this group (Ahmadiyah) is deviant and misleading (sesat dan menyesatkan). And [the World Mosque Council] recommends issuing a fatwa which declares Qadiyaniah (Ahmadiyah) to be outside Islam... It is, therefore, hoped that the (Indonesian) Ministry (of Religion)...undertakes appropriate actions to ban the activities of the (Ahmadiyah) and explains its deviant and heathen nature to the religious people of Indonesia" (Platzdasch, 2011: 6).

True-fasle orientation to religious truth has been implemented in that statement and brought certain epistemological implication in judging 'the other'. While religious freedom pays higher respect to the values of otherness, absolutism and monadism are completely opposed to this idea. Rather than acknowledge the existence of 'the others', absolutism marginalize and exclude them. Thus, the issue is not primarily about legal status of Ahmadiyah but the horizon of 
religious truth and tolerance in the context of religious freedom.

\section{Existential Religious Truth}

The discourse of religious freedom will be continuously in danger if true-false criteria or epistemological religious truth becomes a dominant religious understanding. As mentioned earlier, the logic of absolute/ monolithic is contradictory to the idea of pluralism - which is a basic principle for religious freedom. As a critique toward epistemological religious truth, I would like to offer alternate religious understanding by applying Ricouerian hermeneutical analysis, namely 'existential religious truth'.

Before commencing this discussion, kindly note that the term existential used here to emphasize that religious truth is neither a ready-to-use tool kit nor an adequacy; but rather best understood as a process of expressing and transforming the self. Religious truth is not only pursue "the question of 'what it is' (epistemological problem) but also to ask 'what does it mean to me?' (existential problem)". In correlation with this issue, in post-modern worldview, truth is supposed to be existential: "My experience is the basis for my beliefs, and those beliefs exist to empower me" (McCallum, 1996: 202-203).

Former question tends to create a fixation of truth, meanwhile the latter focuses on realization or manifestation of truth that relies on existential experience. More precisely, religious truth is not a matter of having, but rather a matter of being. As a matter of being, for Ricoeur, "the search for truth is itself torn between the finitude' of my questioning and the 'openness' of being" (Ricoeur, 1965: 51). Following Ricouer's assumption, truth always belongs to certain life-world (lebenswelt), which is the life drama itself: "drama wherein freedom and the body, death and fault, passion and habit, history and private life are the principal challenges for reflection" (Ricoeur, 1965: 156).

Further, truth is not something to be think of, neither to be standardized as mathematical formula or scientific algebra. Instead, truth is something to live with, which in turn will produce certain world-horizon applicable to evaluate the truth itself and establish 'self-understanding'. One might ask bewilderingly: how do we suppose to live by the truth? Is it far more important than "having" the truth itself? (Sugiharto, 1994: 86). While put into the context of religious truth, truth claim is not simply about testing which one is true and which two is not, but more importantly is how this truth can transform someone else's life.

Therefore, it is obvious that Ricouer refutes the principle of objective truth as mediation between reality and perception, between Being and Thing, which in this sense refer to "the principle of identity" (Ricoeur, 1976: 8-9). It argues that truth is neither direct nor immediate. No mediation needed. But, in fact the relation between reality and perception is not direct. It is always mediated through language. To explicate further, let us begin by discussing the dimension of truth. Actually, language does not only function as an instrument, but also as a constitutive element in the process of understanding, just say, as a discourse.

Meanwhile, discourse is the dialectic between "event" and "meaning" which expressed in some propositions. One of the important themes in the literature on truth is its connection to meaning, or more generally, to language. This has proved an important application of ideas about truth, and an important issue in the study of truth itself. (Glanzberg, 2006: 20) Without language, understanding is impossible, indeed. Truth is entirely linguistical, to put in another word: truth does not exist outside language; but instead, fully mediated by language. The production and articulation of truth is constituted in/through language.

By referring to poetic discourse, it is the creativity in composing words that makes truth becomes re-descriptive, speculative, and the possible. For Ricoeur, "the 'being as being-as' of poetic discourse (which is where metaphors abound) is a disclosure of 
how things truly are, but this disclosure is speculative and focused on the ontology of the X" (Simms, 2010: 3). It means is signifies a creative element in language. Since we are extremely dependent on language in order to obtain the truth and self-knowledge, herein emerge hermeneutical problem of truth.

As suggested before, truth is a linguistic event, which involves process of interpreting in/through language. What distinctive here is that language has a capacity to create 'event' by correlating "verbal potentiality and non-verbal actuality" (Ricoeur, 1978: 215). It is parallel with linguistic ability to break the rigid relations between words and the world. In other words, it presents an imperative description of making event that is "even beyond the description of 'seeing as'. Thus, truth is an is, a potential idea and event, not absolute ones. Yet, it has to be discovered within the frame of linguistic event which constitutes a process of intersubjective communication where creativity in linguistic skill is basically required.

Those assumptions originate from Ricouer, in which he argues about hermeneutical activity, which emphasizes the primacy of language. Searching for religious truth is kind of hermeneutical activity that it involves discovering and constructing meaning. Simply, meaning is not waiting somewhere out there to be found. But instead, it is articulated. It is spoken. Interpreting is articulating meaning. There are millions of possible meaning can be articulated. In this sense, language also has million possibilities to create meaning. Therefore, understanding and cognition mean an articulated meaning, which involve process of interpretation by language.

By interpreting, we articulate meaning and by articulating this meaning, we 'create' our self, just say we turn out to be the subject of language. Thus, searching for meaning is synonymic to creating meaning. However, it is not to suggest that we can arbitrarily produce meaning. The point to highlight is that hermeneutical activity is best understood as productive and creative activity rather than a reproductive activity. As a hermeneutical activity, reading text is productive and creative in a sense that our self is transformed through the interpretation process, which applicable in validating the truth of certain religious text and religious truth in general.

Using this alternate perspective, hermeneutical activity will not be dominated with epistemological issue; instead, it has moved further to the ontological-existential (Thiselton, 1992: 345), so-called potentialities of existing (Rabinow and Sullivan, 1979: 129). The salient point to be made is that, interpretation is a moment and event of creative and creation; in another sense, we 'create' ourselves through language. Concerning this topic, Ricouer has composed a very expressive argument as follow:

"To understand is not to project oneself into
the text but to expose oneself to it; it is to
receive a self enlarged by the appropriation
of the proposed worlds which interpretation
unfolds. In sum it is the matter of the text
which gives the reader his dimension of
subjectivity... Reading introduces me to
imaginative variations of the ego. The
metamorphosis of the world in play (in the
text) is also the playful metamorphosis, of
the ego" (Sugiharto, 1994: 84).

Relying on that assumption, Ricouer's hermeneutic further suggests that how to 'question' is far more important than how to 'answer' it. As a logical explanation to this will be briefly described as follow.

First, this questioning method will give us wider opportunities to observe influential situation', which leads to an answer (Ricoeur, 1965: 48). As discussed earlier, both of opportunities and situation are far more crucial than the answer itself.

Second, questioning will stimulate us to be ceaselessly self-reflexive and extroversive while restrain us from being trapped to 'an absolute answer' as well as inertia in thinking.

Third, mentality of questioning signifies mentality of openness. Questioning indicates an open mind, even imaginative thinking since it also involves 'moments of disclosure'. 
The search for truth is more empowered to truth-discovery or the discovery of the meaning of its situation rather than grasping classic definition of truth that concerns to equation of thought to reality (Ricoeur, 1965: 48).

Moreover, it makes us realize the ontological effect of the limit and relativity of our perspective (Moyert, 2010: 730). Put in another manner, questioning method is creative by character, so it enables us to perform transcendent process, in the sense that creates new horizon, which may broaden and enrich ourselves:

"The question is required in order to determine just what issue we are engaging whether it is this issue or that in order to give direction to our attention. Without this no meaningful answer can be given or received. As a question, however, it requires that the answer not be settled or determined. In sum, progress or discovery requires an openness which is not simply indeterminacy, but a question which gives specific direction to our attention and enables us to consider significant evidence" (Mc.Clean, 2003: 61-62).

In the case of Ahmadiyah as previously discussed, the fixation and monopoly of truth makes us reluctant to think creatively and as a consequence, we easily fall to an early judgment (Ricoeur), for example by create discriminative labeling.

\section{The Role of Language and Question in Ahmadiyah Case}

It is interesting to explore further the relation between Ahmadiyah and religious majority from linguistic perspective to see what lies 'beyond epistemological religious truth'. The meaning of Ahmadiyah is articulated in a public discourse as 'deviant' and 'heretical'. In this sense, Ahmadiyah is considered as different, strange: just like an alien stranded in human world. Indeed, truefalse category is applied to test the veracity of Ahmadiyah. Somehow, it shows a linguistic deadlock to understand and sympathize to 'the others'.
Put into another word, there have to be 'new language and vocabulary' to articulate and justify the rights of Ahmadis as certain life-world. Oft-repeated labeling such as 'heretical' and 'deviant' is like a 'dead end' where communication meets failure. It is not surprising though, to ask bluntly- how should communication take place if both sides speak in completely different language? However, there has to be a common language through which communication may possibly occur. This dead end in communication, eventually, constitutes a dead end in language.

Actually, category of 'deviant-believer' is only one set of possibilities available in the field of language. Borrowing the idea of 'linguistic generosity' principle, language has a great potency to yield an alternate meaning. However, it is not impossible to generate 'new meaning' in order to understand 'the others', or Ahmadiyah in this context. 'Linguistic generosity' principles assumes that language poses transformative function, in this sense it has capacity to re-define reality. Simply say, through this transformative function the meaning of Ahmadiyah is constructed within/through language. So, it is through language we can transform the meaning as well as transcend ourselves to the reality that 'Ahmadiyah' perceived as 'the other.'

In this extent, language is no longer dominated with dogmatic-apologetic understanding, but rather move further to post-dogmatic-transformative direction. Basically, this post-dogmatic understanding is required to prolong communication with Ahmadiyah as 'the other'. As suggested earlier, applying dogmatic understanding will be useless, communication will certainly meet a dead end. Instead of considering Ahmadiyah as a distinct life-world with its uniqueness and particularity, it has been judged solely based on its conformity with majority. In dogmatic language and understanding, religiosity is somehow reduced and simplified as 'identity' matter, not as a lively expression.

The tension to potentiate the language capacity to understand otherness, which put 
into the context of religious freedom in today's Indonesia, assumes that religion, somewhat, can be understood as language, so we can make analogy between 'language translation' and 'hermeneutics.' (Takács, 2011: 3). At this point, religious interpretation and language interpretation are analogous. Similarly, dead end in communication as illustrated earlier can be identified as a failure in translation.

Further, translation can act as a model which suit perfectly on discussing religious freedom in Indonesia, particularly when it comes to the topics of 'the other' and 'otherness'. Indeed, communication is possible when two parties involves understands each other. While, in order to understand each other, certainly, needs the power of 'translation.'

Up to this point, translation relates with ethical-philosophical dimension. Angelo Botteno re-formulates Ricouer ideas on 'translation' in a comprehensive manner:

“Translations for him not only a linguistic but also a philosophical issue as far as it regards problems of identity and otherness. A translator is someone who says the same thing in another way. In the act of translation two partners are in relation: the foreigner (foreign work, foreign author, foreign language) and the target reader (who can be the translator himself or somebody else, the public). The translator is in between, that is exactly where his task lies: to be in between two othernesses. Translation is about making connections, linking one culture to another" (Angelo Bottone, 2004).

To explicate further, translation pays greater attention to find out how to prevent a dead end in communication (expand to more extreme point, such as: domination and marginalization). Crucial point to be made is that, how to reach mutual understanding between two parties involved? However, it is not to suggest that there will be no differences exist between them, neither to assume that they should speak in the very same language. Precisely, this is where translation plays its part, to bridge differences between them by firstly relativising universal assumptions. Put in a more succinct way:

\begin{abstract}
"The languages present themselves as singular insofar as the they can never be cashed out into a perfect translation without semantic remainder, and translatable insofar as these two irreducible languages can communicate to and understand each-other nevertheless. Here, through the patient, hospitable work of the translator, the two previously heterogeneous languages are brought into a dialogue with one-another and allowed to learn from the rich cultural and semantic resources unique to each. In other words, the "desire for a perfect translation" has been reworked into the more appropriate "desire to translate" or understand, a desire won through the long practice of "linguistic hospitality" as an attempt to engage with and understand the other without assimilating her into a predetermined universality" (Vessey, 2000: 4-5).
\end{abstract}

Considering the power of 'desire to translate' in the exchange of meanings, then translation is a movement of transcending differences and exposing oneself to the 'test of the Other' (Garcia, 2008: 336-337). In a translational mode of understanding, therefore, we could hope of having a paradigm of forgiveness because of being different from us and the frame of tolerance as central than true-false category. Moreover, through translation we are compelled to leave aside conventional-dogmatic vocabulary to articulate, for instance, the meaning of Ahmadiyah as the other. In this respect, true-false category is no longer applicable. Translation is not about searching for 'the truth', but rather to experience together, or for the sake of what stated in oft-cited Islamic verses, blessing to the worlds (rahmatan lil 'alamin). Simply say, translation is about 'openness to the others.'

For instance, we can treat 'the others' as a friend whom we just met who shares his/ her story ranges from his/her childhood to his/her neighborhood. We may feel amazed, and much more surprised, when find out that there are many interesting aspects in someone else's life which we do not know yet. However, 'listening' is the main (or the greatest) issue here. Surely, listening is not 
a passive activity. It constitutes the ability to absorb information needed to produce a positive feedback. During this learning process, "translation is also extending our ability to listen to others and to assimilate the implications of their feedback for entering more deeply into our own religion" (Mc. Clean, 2003: 63).

An additional point worth making is that, listening enables us to learn from others, to better understand ourselves better, and, eventually, it may lead to new form of sympathy for the other. Henceforth, I would like to elaborate three basic assumptions regarding the ethics of translation and 'listening method' as ethical consequence to/ for draw meaning of the others.

First, 'listening method' assumes that "openness towards the other does not consist so much in surveying others objectively or obeying them in slavish and unquestioning manner, but is directed primarily to ourselves, our self-understanding" (Mc.Clean, 2003: 63). In fact, listening will be more difficult than judging others. At this point, listening method strongly opposes the concept of early judgment as well as epistemological standard, which regard religious truth as a fixed system. Consequently, in dealing with 'resistance' religious majority/state, listening method provokes a space for 'receptivity', i.e, considering Ahmadiyah as an equal interlocutor in a living discourse.

Second, translation model has transgressed 'true-false' category in referring to 'the other'. Instead of considering the others as an obstacle to religious purification, it is best considering them as new source of fruitful information to enrich our selfunderstanding. In addition, it helps us to enhance our skill in listening to others as well as "to assimilate the implications of their answers for entering more deeply into our own religious truth and heritage" (Mc.Clean, 2003: 63).

In the case of religious freedom, resistance is usually coming from certain religious groups of religious majority in terms of keeping the principle of self-identity or regarding themselves as the owner of official religious truth. Through translation model, the existence of Ahmadiyah could be a mediation of knowledge and even an open invitation to improve our wisdom, i.e, to treat Ahmadiyah as a mediation of auto-critique as such that it may contain the possible answers of our own religious question as well. This perspective eventually leads to enrichment of our religious understanding with new vocabularies beyond 'true-false' category.

To sum up, one key concept originated from Ricouer might be useful to interpret the truth, particularly in religious freedom context, namely: openness. Openness is a potential method to discover the truth, which relies on three crucial aspects: the intersections among the world horizon, the primacy of asking, and awareness to limitation of our perspective. These components could be an inclusive frame of thinking outside 'truefalse' category in viewing an reflecting the existence of Ahmadiyah as the other.

In this sense, as a hermeneutic discourse, life-world (Lebenswelt) can be a good source and reference to unfold the religious truth. Lebenswelt constitutes the world we live in, a place where our existential aspirations as a human being grows vigorously, and a site where we exchange meaning perpetually. Religious truth is deeply rooted inside the Lebenswelt; and, herein religious truth is framed not as a system, but rather as a lively living thing. This means, the way we experiencing life inside this Lebenswelt will produce a horizon of living-truth.

Consequently, the reference framework of Lebenswelt will work better as a 'horizon' by stimulating the emergence of new possibilities, a new being-ness, a new self, rather than looking for fixed, certain and static answer for the truth. To be briefer, religious truth signifies an infinite horizon, which always asks for new definition, as truth is rooted firmly in a dynamic basis of Lebenswelt.

In such frame of Lebenwelt, the experience of exchange of meanings, aspirations and truth are actually taking place, especially 
between religious majority and Ahmadiyah, where religious truth is imagined as a living truth raher than fixation of truth. Within the framework of Lebenswelt religious truth is a process and project of exchange to shape self-understanding; far from the search for a single truth or the unity of truth, it constitutes 'suspension of truth.'

Consequently, rather than viewing religious truth as a certainty, religious truth as a 'suspense' becomes an unlimited opprotunity for religious majority and Ahmadiyah to discover together 'something more'. In other wrods religious truth is a mater of becoming true. Furthermore, Lebenswelt provides a living foundation to discover the truth in 'historicity'. This is the reason why when conceived as a history, Lebenswelt reflects a vague shadow of truth, which challenge us to find the dimension of the inexhaustibility of truth which will always be waiting for us up front that challenges both religious majority and minority. Therefore we need to place truth within its eschatological character of unity which will be parallel with placing truth as a historization (Ricoeur, 1965: 185-186).

Consequently, Ahmadiyah must be placed in the frame of historization of indonesianess where we grow together or being as. Thus, at least it would prevent the forms of alineation in the level of mutual understanding, the dictatorship of single truth and provide 'infinite formulations of truth' which are also beyond language that formulate it. Instead of single truth, historical frame of interpretation opens the possibility of various and multiple truths:

"No one individual, no one historical period, can claim to have exhausted the exploration of truth, or rather to have opened itself totally to the manifestation of truth. Each individual and each period, instead, is called to make his original contribution to this opening up of truth (22). As Pope John Paul II said in his peace message for the year 1985: "Man's journey through history is like a pilgrimage of discovery" (Fedrigotti, 1985: 8).
Herein I offer some insights originate from Ricouer's theory of interpretation: (1) Religious freedom is closely related with the matter of truth, which based on existential principle as follow: desire to be, desire to live, desire to exist, rather than desire to know. Hence, religious truth is a 'living truth,' the truth about our existence, our beingness, or our deepest aspiration as human being; not as justification to our belief; (2) interpretation is a mode of being, which involves the activity of interpreting, as well as creating ourselves. Thus, religious truth will lead to selftransformation through 'listening to others.'

\section{The Other as Mediation to Self- Understanding}

The case of Ahmadiyah is corralated to the frame 'true-false' in jugding the existence and sense of the other. The mode of existential understanding, found in Ricoeur's hermenutics, can be helpful and valuable in interpreting religious truth and elaborated to accommodate the other, put in religious freedom context. As previosly discussed, lack of acknowledgment of the other is a result of the fixation and monopoly of the truth. As exemplified in the case of Ahmadiyah, the discourse of religious truth can be translated as a failure to interpret the other as a mediation to achieve self-understanding.

Here Ahmadiyah is considered as an obstacle to purify religious truth and self. It is not assumed as a mediation to enrich and broaden self-understanding. Because religious freedom constitutes sociological version of being-in-the-world-with-others, therefore it is crucial to further investigate the meaning and the existence of 'the others'. Actually, there is one basic principle in Ricouer's hermeneutics, that the others should be placed beyond epistemological true-false category. Yet, it may also become an authentic source to self-knowledge and understanding (Ricouer, 1965: 49).

Self-understanding is not direct, but rather mediated by the others. It should be noted that, the truth claim, put into the context of religious freedom, will encourage 
us to learn from each other. Of course, it is not intended to looking for justification to which one is true, and which one is not. The main important thing is, how to experience together, which is aim at searching for 'disclosure moment', namely to actively participate in finding the horizon of truth as well as self-understanding along with the others. Henceforth, a few important points need to be outlined to argue the importance of involving the other as part of interpreting religious truth and self-understanding, which simply note as ethical implication of being-in-the-world-with-others.

First, the other functions as mediation. As a mediation, the others is a 'filter' or 'ideological auto-critique' (Suratno, 2005: 111-116) to any narrow self-understanding, and also to the meaning of religious truth which lies its assumption a priori to selftransparent model. It has to be admitted that the existence of the other as a mediation may stimulate 'confrontation.' On the other hand, it will stimulate sympathetic imagination to the others, which surpass the desire for objectivity, known for its true/false approach, as previously discussed. This imagination, then, leads to the suspension of truth, which possibly applied to the others. Basically, imagination always provides surplus of meanings for an imagined object. Imagination is always free so that it may provide an empty space for so-called 'generosity' or 'abundance of heart' which in turn enables the truth of others to grow its seed (Ricoeur, 1965: 161).

Second, the others functions as a suspension not as an obstacle neither threat to self-understanding (Ricoeur, 1965: 49). As a suspension, the others define truth as unceasingly dialectic process, because its role as interlocutor involves criticizing, questioning, and destabilizing the established perception of truth. And, more importantly, it gives opportunities to evaluate the self and to explore richer and wider authenticity and self-understanding. The fruitful insight that comes from the other further unfolds another fact of the truth per se, which becomes a basic characteristic of an inexhaustible and possible truth. Briefly, it is 'through the other' that is more effective to open up possibilities to those kind of truth.

Third, the others function as an act of recognition. Recognition reflects rejection to any irreducibility of identity while acknowledge the others as a demand to intersubjective relationship. As hermeneutical discourse, this recognition becomes a common principle in inter-subjective relations, which means placing the others in the main position and further acts as interlocutor. The act of recognition, in turn, leads to the recognition toward the primacy of communication in order to obtain inter-subjective definition of truth (Ricoeur, 1965: 51).

Simply note that, communication is the structure of true knowledge. The structure of communication tends to eliminate clear and distinct self-knowledge, self-immediacy of knowledge, which concerns more with context, event, and discourse that generates the truth rather than the 'formation' of truth itself. Thus, those three assumptions work simultaneously to place the other within the matrix of humanity.

\section{CONCLUSION}

Precisely, truth is more than just epistemological matter; but rather imagined as an openness of our being to question others and the possible. Lack of existential ontology in assessing the truth, which may be used to interpret religious truth- considered as a license to judge and even to eliminate another truth. Oppose to this idea, Ricouer's hermeneutics opens up an alternate point which enables us to transgress true-false category and keep us away from falling into monopoly of the truth by emphasizing more on interpretation of truth as a ceaseless process through which we all strive for the demand of being is being for others. In addition, truth is a matter of questioning, suspending judgments, and constituting a 'process of becoming' rather than obtaining a final or objective truth. And finally, truth is about to recognize the others as basis for richer and wider self-understanding. 


\section{BIBLIOGRAPHY}

Andi R, R. Ferdian, 2011, SKB Pemicu Kekerasan Ahmadiyah. February 7, 2011, Retrieved on June 23, 2012 from http:/ / www.inilah.com

Brockelman, P. T, 1992, The Inside Story: A Narrative Approach to Religious Understanding and Truth. Albany: State University of New York Press.

Bottone, A, 2004, "Translation as Ethical Paradigm in Paul Ricoeur," , June 5, 2004, Retrieved August 2 from http://opp.weatherson.org/ archives/002629.html.

Fedrigotti, L. M, 1985-1986. “A

Theory of Christian and Biblical Hermeneutics," Theology Annual, vol. 9-10, Retrieved April 5, 2012 from http://www.shanxixiuyuan. com/sxnk/annaul/ A009g.htm

Garcia, L; 2008, "Paul Ricoeur and the Translation-Interpretation of Cultures," Melintas, (23) 3, Bandung: Prahyangan Catholic University.

Garret, James Leo, 1978, Advocates of Religious Toleration and Freedom, Retrieved on June, 2012 from http://www. preciousheart.net/religious $\% 20$ freedom/Advocates_3a.htm

Glanzberg, M, 2006, "Truth," Jun 13, 2006, Retrieved August 2, 2012 from Stanford Encyclopedia of Philosophy, plato.stanford.edu/entries/ truth/

Hasani, I and T, Bonar, T 2012, Politik Diskriminasi Rezim Susilo Bambang Yudhoyono, June 2012, Retrieved on July 20, 2012 from http:// www.setara-institute.org/sites/ setara-institute.org/files/Reports/ Religious\%20Freedom/120127BB2011_Politik_Diskriminasi_ Rezim_SBY_rev.pdf
Lakoff, G and Johnson, M; 2003, Metaphors We Live By, Chicago and London: The University of Chicago Press.

McCallum, D; 1996, The Death of Truth, Minneapolis: Bethany House Publishers.

Moyaert, M; 2010, “Interreligious Dialogue and the value of Openness: Taking the Vulnerability of Religious Attachments into Account", The Heythrop Journal, Vol. 51, Oxford: Blackwell.

Neville, R. C. (ed.), 2001, Religious Truth: A Volume in the Comparative Religious Ideas Project, New York: State University of New York.

Nordholt, H. S; 2008, "Soft State, Citizenship, and Identity Politics: An Essay", Journals of Indonesian Social Sciences and Humanities, Vol. 1, Retrieved on July 5, 2012 from http//www.journals-kiltv.nl/php/ jissh/index

Platzdasch, B; 2011, "Religious Freedom in Indonesia: the Case of the Ahmadiyah,"

Institute of Southeast Asian Studies, Retrieved on August 4, 2012 from http:// web1.iseas.edu.sg/wp-content/ uploads / 2010/11/ReligiousFreedom-in-Indonesia1.pdf

Ricoeur, P; 1978, The Rule of Metaphor: Multi-disciplinary Studies of the Creation of Meaning in Language, London: Routledge \& Kegan Paul

Ricoeur, P; 1976, Interpretation Theory: Discourse and the Surplus Meaning. Texas: Texas University Press.

Ricouer, P; 1965, History and Truth, Evanston: Northwestern University Press. 
Rabinow, P and Williams Sullivan (eds.), 1979, An Interpretative Social Science: A Reader, Los Angeles: University California Press.

Simms, K, 2010, "Review on Gert-Jan van der Heiden: The Truth (and Untruth) of Language: Heidegger, Ricoeur and Derrida on Disclosure and Displacement," Retrieved on August 2, 2012 from http://ndpr.nd.edu/ news $/ 24536 /$ ?id $=21870$

Suratno, 2005, "Pluralisme Agama dalam Hermeneutika Paul Ricoeur," Jurnal Paramadina (4) 1, Jakarta: Paramadina University, Retrieved on February, 2 from suratno77.multiply.com/reviews/ item $/ 3$

Sugiharto, I. B; 1994, “The Primacy of metaphor in postmodern philosophy." Dissertation Thesis, Romae: Facultate Philosophiae apud Pontificiam Universitatem S. Thomae.
Thiselton, A. C, 1992, New Horizons in Hermeneutics: The Theory and Practice of Transforming Biblical Reading, Glasgow: Harper Collins.

Takács, A; 2011, “Fragile Identies: Towards a Theology of Interreligious Hospitality by Marianne Moyaert," Retrieved on June 12, 2012 from http://www.comparativetheology. org/?page_id=255

Undang-Undang Dasar Negara Republik Indonesia Tahun 1945, 2012, Retrieved on July 12, 2012 from http:// id.wikisource.org/wiki/UndangUndang_Dasar_Negara_Republik_ Indonesia_Tahun_1945

Vessey, D; 2000, “The polysemy of Otherness: On Ricoeur's Oneself as Another," Retrieved on July 3, 2012 from http:/ / www.davevessey.com/ Vessey_Ricoeur.html 